UCIR 20412

\title{
PHYSICAL AND CHEMECAL CHANGES TO ROCK \\ NEAR ELECTRICALLY HEATED BOREHOLES \\ AT SPENT FUEI, TEST-CLIMAX
}

\author{
J. M. Beiriger \\ W. B, Durham \\ F. J. Ryerson
}

January 1985

This is an informal report intended primarily for internal or limited external distribution. The opinions and conclusions stated are those of the author and may or rasy not be those of the Luboralory.

Work performed under the ausplices of the U.S. Department of Energy by the Lawrence Livermore National Laboratory under Contzact W-7405-Eng-48.

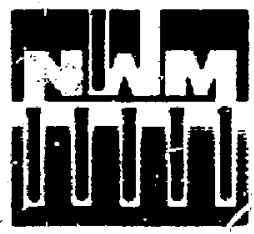

Nuclear Waste

Manegement

Projects 


\title{
PHYSICAL AND CHEMICAL. CHANGES TO ROCK NEAR ELECTRICALLY* HEATED BOREHOLES AT SPENT FUEL TEST-CLIMAX
}

\author{
J. H. Beiriger \\ W. B. Durham \\ F. J. Ryerson
}

UCID -20412

DE85 010834

ABSTRACT

Sections of Climax Stock quartz monzonite taken from the vicinity of two electrically heated boreholes at Spent fuel Test-C: $\max ($ SFT-C) have been studied by scanning electron microscopy and optical microscopy for signs of changes in crack structure and in mineralogy resulting from operations at SFT-C. The crack structure, as measured by densjty 0 : cracks and average crack Jengths was found not to have changed as a resul of heating, regardless of distance from the heater hole. However, rock near t.le heater borehole sampled in the nortt. heater drift was found to be more cracked than rock near the borehole sampled in the south heater drift. Mineralogically, the post-test samples are identical to the pre-test samples. No new phases have been formed as a result of the test.

\section{DISCLAIMIAR}

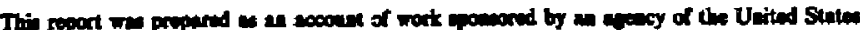

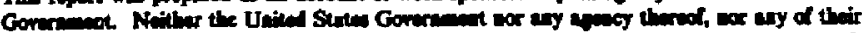

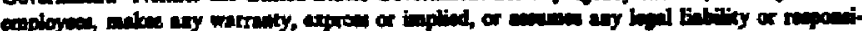

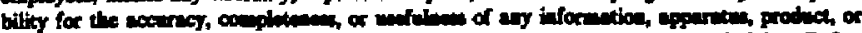

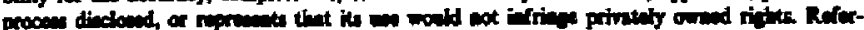

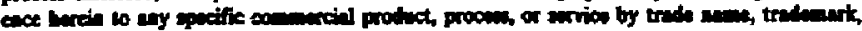

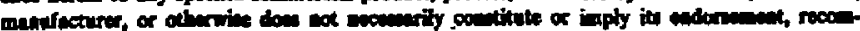

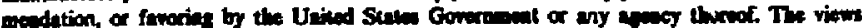

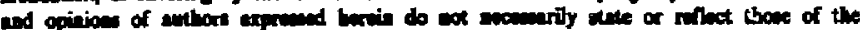
United Stales Gontrient or ay enougy thereor.
\end{abstract}

\footnotetext{
${ }^{\star}$ This study was conducted as part of the Nevada Nuclear Waste Storage Investigations of the U.S. Department of Energy.
} 
INTRODUCTION

The recently concluded Spent Fuel Test-Climax (SFT-C) has tested, with an in situ experiment, some of the concepts of an underground repository for spent nuclear fuel (Ramspott et a1., 1979). The present study is one of several observational and laboratory studies in support of SFT-C aimed at determining the combined and separate effects on rock of nuclear radiation, heat, and mechanical load. The aim of this study is to determine the effect on rock of heating alone.

The SFT-C is located in workings at the $420-\mathrm{m}$ level below the surface in the quartz monzonite portion of the Climax Stock at the Nevada Test Site. The stock is unsaturated but rot dry at this level. The water table is about $150 \mathrm{~m}$ below the test level. Canisters of spent nuclear reactor fuel were emplaced in an array of boreholes, intermixed with boreholes containing electrical simulators which duplicated the heat of the nuclear waste but not the nuclear radiation (Figure 1). In the north and south heater drifts of SFT-C additional electrical heaters were placed in $60-\mathrm{mm}$ diameter boreholes to provide thermal boundary conditions on the array of spent fuel canisters and simulators. The rock near the electrically heated boreholes in the north and south heater drifts were hotter than at any other location in the SFT-C facility because the power output of the heaters was higher and because the rock was nearer the heat source than was the case in the main array. It was reasoned that if heat caused physical and chemical changes to any rock at SFT-C, it would be most pronounced at the walls of these bcreholes. 
SAMPLE LOCATION

Pre- and post-test cores were taken from the vicinity of two of the electrical heater simulator boreholes: borehole five in the south heater drift, designated SHH5, and borehole ten in the north heater drift, NHHIO. Three cores were taken from each borenole (Figure 2), one pre-test and two post-test. The pre-test core was simply the 25-mm-dianeter core from the $A X$ borehole made for the electrical heaters; their desigrations are those of the boreholes themselves: SHH5 and NHHIO. Following the completion of testing operations at SFT-C and the removal of the heaters, a 150-mm-diameter core was taken approximately tangent to the heater borehole. This core was given the additional designation "PT" for "post-test". Core NHHIOPT actual1y intersected the heater borshole, providing visual proof of the spatial relationship of pre- and post-test cores. Core SHH5PT barely grazed the heater borehole. The orientation of SHH5PT with respect to SHH5 was based on a fiduciary stripe made along the length of the core, and its distance from the wall of borehole $\$ H K 5$ was calculated to be $3.7 \mathrm{~mm}$ based on measurements of core diameters and of the web between boreholes SHHS and SHH5PT. The secorid post-test core, designated with an "A" suffix, was NX-size (45 mn outer diameter) and was cored parallel to, and at a radius of $760 \mathrm{~mm}$ from, each heater borehole.

The intervals of core which we sampled in this study were chosen to lie at a depth near the horizontal midplane of each $2.5 \mathrm{~m}$-long heater, and at the same depth as one another, consistent with the retrievability of material. Thus, the sections used from cores SHH5, SHili5PT, and SHH5A all lay in the 
4.05-m to 4.15-m interval. The sections from cores NHH10, NHH1OPT, and NHH1OA lay in the $4.18-m$ to $4.27-m$ interval. The exact relationship of these intervals to the positions of the heaters can be seen in core logs from the pre-test cores (Tewes, 1982).

The original reason to sample rocks from the vicinity of two different heater boreholes was to compare the effects to rock under different moisture conditions, given the potential physical and chemical changes heated water can bring about. In fact, the two heater boreholes we sampled may not be very different as regards water. Borehole SHHS was cored into relatively dry rock (although dampness pervades the whole formation at this depth) and was located directiy below a water-bearing shear zone which actively seeped water on the mine floor around SHH5. Borehole NHHIO intersected a major high angle structural feature known as the Receiving Room Fault, a broad, variably altered and clay-infilled zone roughly $4 \mathrm{~m}$ wide which also seeps water. The core $\log$ for NHHIOPT confirms the intersection with the altered zone at depths surrounding the interval we sampled. The core $\log$ for NHHIDA indicates the 2 one is more than a meter above the interval we sampled.

SAMPLE PREPARATION AND EXAMINATION TECHNIQUES

Sections of rock were prepared as polished sections for scanning electron microscopy (SEM) and as polished thin sections for optical microscopy (OM) and electron probe (EP) analysis. The polished sections and thin sections were prepared as matched facing pairs as shown in Figure 3. The cutting process went as follows: the core intervals were first sliced along vertical diametrical planes to reveal the face of interest. In the case of the "PT" 
core, the slice was radial to the heater borehole; the azimuthal orientation of the slices in the other cores was arbitrary. Squares approximately $23 \mathrm{~mm}$ on a side were then cut from the faces of interest. Fourteen such square's were cut from the vicinity of each of the two heater boreholes (Figure 2): two from the pre-test core, ten from the "PT"-designated core, and two from the "A"-designated core. By the arrangement shown in Figure 2, the horizontal temperature gradient around each heater borehole was thus sampled twice, in parallel, adjacent rows. The locations of all 24 post-test sections are listed in Table 1.

In order not to confuse the twenty-eight pairs of sections as to their locations and faces of interest, various patterns of identifying notches were cut into the rock slabs as they were cut into squares. The notches also served to register facing SEM and OM sections. The cutting process was documented with color photographs, and all scrap material was retained, in order that petrographic features would serve as backup location identifiers.

Once all the squares had been cut, approximately $1 \mathrm{~mm}$ of material was ground from the faces of interest to remove cutting damage. Those faces were then ground flat with $S i C$ powder in a sequence of steps from 240 to $1900 \mathrm{grit}$ size. The sequence of steps shown in Figure 3 was then carried out.

Thin sectioning and polishing were carried out in standard petrographic fashion by Pacific Petro Labs, Mokelume Hill, CA. Thin sections were

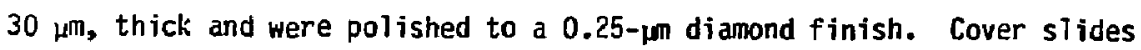
were not attached. Note that because of the way in which we generated matched 
pairs of sections, the thin section slices were supplied to Pacific Petro already mounted on glass slides. The thick polished sections were polished to a 1.0-jm diamond finish. They were nat impregnated prior to polishing.

The thin section: were examined in the state received from Pacific Petro. The thick sections were given further treatment to prepare them for SEM, as prescribed by Sprunt and Brace (1974): The surfaces were first ion-milied (argon ions, $7 \mathrm{kV}$ accelerating voltage, $15^{\circ}$ milling angle, 12 hour milling time) to remove the remaining fine damage caused by mechanical polishing, then were coated with a layer of carbon roughly $40 \mathrm{~nm}$ thick to prevent surface charge buildup under the electron beam.

Crack counting techniques. For crack counting we used the rapid, semi-automatic technique developed to measure subtle physical changes (i.e. microfracturing) in CTimax Stock quartz monzonite (CSQM) (Durham et al., 1984). To avoid operator bias toward "interesting" areas, SEM photos were taken at preassigned locations. Straight line "scans" were taken across each section and micrographs were taken at 2-mintervals along the scans. Micrographs were taken at a magnification of $500 \mathrm{x}$, using a solid-state under quadrupole backscattered electron detector in the SEM. The cracks we counted were only those considered "fresh" (sharp edges, no fili material, pieces fit together; see Durham et al., 1984, for more detail). Our earlier studies demonstrate that such "fresh" cracks inciude a significant background density of cracks existing prior to operations at SFT-C. However, any new cracks developed by such operations certainity fall in the "fresh" category. Grain boundary cracks present a more ambiguous image in the SEM than intragranular 
cracks mainly because of the obscurring contrast introduced by grain-to-grain chemical changes, and, as in the previous studies, were deliberately ignored in the interests of maintaining crack counting efficiency. The possible effect of ignoring grain boundary cracks in this study is analyzed under DISCUSSION below.

Microanalytical Techniques. Polished thin sections of all samples were examined in plane, cross-polarized, and reflected light in order to determine primary igneous and secondary phase mineralogy and textures. Subsequent to petrographic analysis the five samples from NHH1OPT (numbers 1-5) were selected for microprobe analysis. The microprobe analyses were conducted with a $2 \mu \mathrm{m} \times 2 \mu \mathrm{m}$ rastered beam at 15 na sample current (measured in a Faraday cup) with a $15 \mathrm{kV}$ accelerating voltage. For each sample, 300 analyses were obtained along six, 50-point traverses per sampie with a step interval of 400 um. The data were sorted into mineral groups using stoichiometry and analytical totals as discriminants. After microprobe analysis, the samples were stained for plagioclase and K-feldspar and analyzed for modal abundances.

RESULTS

Crack Counting. Two scans were made across each of the 28 SEM sections, in the sequence given in Table 2. The first scan ran horizontaily in the SFT-C coordinate system (i.e. radially from the heater borehole for the "PT"-designated sections), the second vertically. Eight to ten spots were counted on each scan (identification notches eliminated some of the spots). In all, 480 spots were photographed, and 1245 fresh cracks were identified and 
measured (Table 3 ). Tables 4, 5, and 6 give the results: three crack parameters (described below) are given sumarizing the measurements for each of the 28 SEM sections, and the tables are arranged to resembie the original geometrical arrangement of the sections. Additionally, Tables 4 and 5 give summary measurements for sections grouped by heater borehole.

The three crack parameter's are areal number density of cracks in $\mathrm{mm}^{-2}$, average length of individual cracks in $\mu \mathrm{m}$, and areal total length density in $\mathrm{mm} / \mathrm{mm}^{2}$. The third paraneter is exactly the product of the first two, but its presentation does serve a purpose. Firstly, it is calculated by a means other than simply taking the product of the first two parameters, thereby serving as a check of the calculations, and secondly it is usually the most sensitive of the three parameters since it has the combined sensitivity (and noise) of the first two par c...eters.

None of the three crack parameters is normally distributed, so the means and siandard deviations given in Table 4, which were calculated on the basis of a normal distribution, are useful only for qualitative comparisons. Crack lengths turn out to be log-normally distributed (Figure 4) consistent with a similar finding by Weed and Durham (1982) on CSOM. The log-normal means and standard deviations for crack length given in Table 5 do allow quantitative statistical tests for trends. Neither crack number density nor total length density is log-normally distributed, also consistent with the findings of Weed and Durham (1982). 
Table 6 gives detailed measurements for the horizontal traces oniy on the four "PT" sections closest to the heater holes (Figure 2, Table 1). Since the temperature gradient was strongest and since temperatures were highest along these four traces, trends might be expected to appear in the spot-to-spot data. Note that in Tables 4 and 5, such spot-to-spot detail is averaged across each section.

Petrography and Mineral Chemistry. Petrographic examination of post-test samples shows no differences between the samples from NHHIOPT and SHH5PT. Near both boreholes, the mineralogy compares favorably with that of the deuterically altered pre-test samples (Table 7 ). The samples are composed of a groundmass of subhedral grains of oscillatory zoned plagioclase, quartz, K-feldspar and biotite ranging from 0.5-2.0 $\mathrm{mm}$ in diameter. Comon accessory phases include titanite (also present as an alteration product), allanite, $z$ ircon, and apatite. In the samples examined, quartz and $K$-feldspar phenocrysts up to $10 \mathrm{~mm}$ and $30 \mathrm{~mm}$ in diameter, respectively, are found.

In these deuterically altered samples, the worothermal alteration is found predominately on plagioclase and biotite within the rroundmass. Plagioclase is altered to muscovite plus trace amounts of epidote and clinozoisite. The volume percentage of plagioclase altered is less than $5 \%$. Biotite is altered to chlorite, epidote and titanite. In more intense alteration, muscovite may be present on biotite. In previous studies, it has been shown that intense alteration is localized near healed fractures which carried the hydrothermal solutions (Ryerson and Qualheim, 1983). The lack of intense alteration from NHHIOPT and SHH5PT is consistent with the absence of healed fractures in these samples. 
A major finding of this work is that no additional phases have beer formed as a result of heating at SFT-C. Due to this finding and the lack of any demorstrable difference between NHHIOPT and SHH5PT, additional analysis concentrated on the NHHIOPT samples.

Modal analyses of NHHIOPT samples are given in Table 7. An average from 19 deuterically altered samples from Connolly (1981) is given for comparison. The major varlation amorig phases is between quartz, plagioclase and K-feldspar and is attributed to primary igneous processes (Ryerson and Qualheim, 1983). A plot of modal abundance versus distance from the heater indicates that no systematic variations in abundance exist with respect to heater position (Figure 5).

In order to assess the extent of ion exchange reactions which may have been produced during the test, feldspar analyses from the NHHIOPT samples are given in Table 8 and plotted versus distance from the heater in Figure 6 . As shown for pre-test samples, the standard deviation among the plagioclase analyses is greater than that among the K-feldspars. This is attributed to primary igneous zonation (Ryerson and Qualheim, 1983). The compositions of these feldspars do not vary as a function of distance from the heater. Also the average composition of plagioclase and $\mathrm{k}$-feldspar, $31.3 \%$ An and $89.7 \%$ Or, respectively, compares favorably with average compositions of ali the samples from pre-test analysis, $31.2 \%$ An and $88.6 \%$ Or, respectively (Patrick et al., 1984). 
DISCUSSION

Cast in the model of a normal distribution, the crack measurements show a great deal of scatter and two important "non-trends" (Table 4): 1) There is no systematic decrease in physical damage in the post-test care in the radial direction eway from the heater boreholes, and 2) there is no apparent difference in crack structure between pre- and post-test core. The magnitude of the measurement scatter agrees very well with previous measurements on CSCM (Weed and Durham, 1982; Beiriger and Durham, 1984). The magnitudes of the three crack parameters are very close to those measured by the same operator under the same SEM conditions (Beiriger and Durhan, 1984, passes $B$ arid $C$ in their Table 4).

There is a strong suggestion that the crack structure is not the same in the vicinity of the two heater boreholes. Taking pre- and post-test core together (consistent with "non-trend" 2, above), the number density of cracks in the 14 sections from NHHO appear higher than densities in the corresponding 14 section from SHH5. The averages over a11 14 sections show $25 \%$ higher number density in NHH1O as compared with SHH5 (Table 4). It is intuitively difficult to ascribe the consistency of this trend to chance, but lacking a plausible distribution model for srack density, the probability of this trend being the result of random measurement fluctuation cannot be calculated. The average length of cracks near NHH1O is also higher (Table 5), and a statistical test can be applied here, since the distribution is log-normal. The $t$ statistic for 1245 measurements is 1.970 , meaning that in a two-tailed test (i.e. a difference of either sign) a randon sampling of a 
normal distribution will produce the observed difference on average one time in 20. Combined with the qualitative inference based on crack density, this $t$ statistic provides a firm argument that the crack structure of core taken near NHH1O is different from that of core taken near SHH5. A plausible explanation of the longer and more populous cracks near NHH10 is the fact that 12 of the 14 sections examined from NHHIO (a1f but NHHIOA-1 and -2) apparentiy fell within the limits of the Receiving Room Fault (RRF). The hypothesis could be tested by counting several hundred cracks from a few meters on ei iher side of the RRF. It is interesting to note that there is no macroscopic physical evidence of the proximity to the RRF in the $90 \mathrm{~mm}$ lengths of core supplied to us from NHH10 and NHHIOPT. Thus our observations may support the phenomenon frequently observed in laboratory test specimens that microfraciuring is a precursor to macroscopic failure.

There is a qualitative trend in the crack density in the NHHIOPT core: the measured density is higher towards the outer cylindrical surface of the core (Table 4). The trend appears in both rows of sections in core RHHIOPT but does not appear in the average length measurement nor in any of the measurements of core SHHSPT. The trend is interesting because Weed and Durham (1982) saw a similar, albeit very poorly resolved, trend in another $150-\mathrm{mm}$ core from CSQM. A firm conclusion is beyond the capacity of the measurement made so far. The coincidence, however, is noteworthy.

We have measured no physical damage to the host rock caused by the heater hole environment. Does this imply that the rock in fact has suffered no physical damage? There are a number of routes by which damage could have 
escaped our detection. (1) Damage levels may be below our measurement resolution. In this case the effect on physical properties of the rock would probably also be small. (2) Cracks narrower than our practical resolution limit of $0.1 \mu \mathrm{m}$ may exist. The effect of such cracks on physical properties depends on their density and geometrical arrangement, but the potential for important effects is not strong (See Kranz, 1983, for a review). If such cracks were caused by operations associated with SFT-C, it is possible that they were once wider in the presence of the high temperatures and gradients around the heater boreholes. It is, of course, possible that cracks seen now are wider than they were in situ, now that confining stresses have been relieved. (3) Damage was confined to grain boundary cracks. CSQ4 does exhibit loosened grain boundaries, but the number of such cracks is small. Roughly 1 crack in 5 is a grain boundary crack, based on a qualitative examination of photomicrographs used in our several crack counting studies. Grain boundary loosening appears in pre- and post-test core, and in rock which has been mechanically, rather than thermally, stressed. If confined to grain boundary cracks, the damage would be difficult to resolve quantitatively by direct observation. (4) Damage was manifested in some parameter (such as interconnectivity) which we did not measure. However, it is difficult to perceive how such damage could have occurred without affecting the density and/or length of intragranular cracks. (5) There is a remote possibility we have missed the forest for the trees, that is, the damage is concentrated in long cracks. In fact the maximum detectable crack length of a straight crack using our semi-automated technique is that of a long crack whose length is truncated at opposite corners of a micrograph, $7 . e .$, about $300 \mu \mathrm{m}$. This is probably the main cause of the slight departure of crack length distribution 
from log-nomality at Ionger lengths (Fjgure 4). Millimeter-scale and longer cracks are, in fact, plentiful in CSQ, they appear clearly in the low magnification mapping micrographs we take as part of the counting technique. However, such cracks appear in both the pre-and post-test sections with roughly the same frequency.

The strong detection of a difference in crack structure ili two populations (NHHIO and SHH5) is unprecedented in the two previous studies using the semi-automated crack counting technique. Heretofore we found small, qualitative trends for which strong statistical support could not be generated. We have thus demonstrated that combined differences in crack density of the order of $25 \%$ (Table 4 ) and in average crack length of the order of $10 x$ (Table 5) are detectable with a reasonable amount of effort.

No mineralogical changes due to hydration, dehydration or cation exchange reactions as a result of the test have been observed. If the wall rock was in contact with water during the test, then a number of the phases present should have been unstable. In fact, since the wall rock temperature was well in excess of $100^{\circ} \mathrm{C}$, free water was driven off and some of the hydrous phases may also have been unstable. The absence of any reaction products indicates that the duration and intensity of the thermal maximum was not sufficient to overcome the activation barriers for these reactions, i.e. the kinetics were too sluggish. 
CONCLUSIONS

Sections of Climax Stock quartz monzonite taken frow the vicinity of heater holes NHH1O and SHH5 at Spent Fuel Test-C1imax (SFT-C) do not show any change in their crack structure, as viewed by scanning electron microscope, resulting from the in situ heating which occurred. In particular, rock sampled at intervals along the temperature gradient away from the heater boreholes shows, within measurement resolution, the same density of cracks and average length of cracks as rock sampled before the heaters were powered up.

There is a significant difference from NHHIO to SHH5 in crack structure of rock sampled in the vicinity of the heater holes. Rock near NHH1O has more cracks per unit area (by roughly 25\%), and its cracks have a longer average length (by roughly 10\%), than rock near SHH5. The augmented cracking near NHH]O may be explained by the proximity of MHHIO to the Receiving Room Fautt, a major geologica] feature intersecting the mine workings at SFT-C.

Mineralogically, the post-test samples are identical to the pre-test samples indicating the reaction $k$ inetics for hydration, dehydration and cation exchange reactions are too sluggish to be overcone by a test of this intensity and duration. 


\section{REFERENCES}

Beiriger, J. M.\& ar, W. B. Durham, SEM studies of stressed and irradiated Climax Stock quartz monzonite, University of Californja, Lawrence Livermore Nationa1 Laboratory Report UCID-20052, 1984.

Connolly, J. A., Hydrothermal alteration in the Climax granite stock at the Nevada Test Site, M.S. Thesis, Arizonā State University, Tempe, AZ., 1981.

Durham, W. B., J. M. Beiriger, and H. C. Weed, A rapid technique for counting cracks in rocks, Scanning Electran Microscopy, in press, 1984.

Kranz, R. L., Microcracks in rocks: A review, Tectanophys., 100, 449-480, 1983.

Patrick, W. C., T. R. Butkovich, R. C. Carlson, W. B. Durham, H. C. Ganow, G. L. Hage, E. J. Majer, D. N. Montan, R. A. Nyholm, N. L. Rector, F. J. Ryerson, H. Weiss, and J. L. Yow, Jr., Spent Fuel Test - Climax: Technical measurements interim report Fiscal Year 83 , University of California, Lawrence Livermore National Laboratory Report UCRL-53294-83, 1984.

Ramspott, L. D., L. B. Ballou, R. C. Carlson, D. N. Montan, T. R. Butkovich, J. E. Duncan, W. C. Patrick, D. G. Wilder, W. T. Brough, and M. C. Mayr, Technical concept for a test of geologic storage of spent reactor fuel in the Climax granite at the Nevada Test Site, University of California, Lawrence Livermore National Laboratory Report UCRL-52796, 1979. 
Ryerson, F. J. and B. J. Qualheim, Mineralogic and petrologic investigation of pre-test cores from Spent Fuel Test-Climax. University of California, Lawrence Livermore Laboratory Report UCIO-19976, 1983.

Sprunt, E. S. and W. F. Brace, Direct observation of microcavities in crystalline rocks, Int. ‥ Rock Mech. Min. Sci., 11, 139-150, 1974.

Tewes, H. A., ed., Research results reported by 0 EO summer (1981) student employees of LLilL working with Earth Sciences (K) Division personnel, University of California, Lawrence Livermore National Laboratory Report UC10-19303, 1982.

Weed, H. C. and W. B. Durham, Drilling-induced borehole-wall damage at Spent Fue 1 Test-Climax, University of California, Lawrence Livermore National Laboratory Report UCID-19672, 1982. 
TABLE 1: Location of post-test sections

(Numbers qive range of distance, in $\mathrm{mm}$, to wall of heater hole)

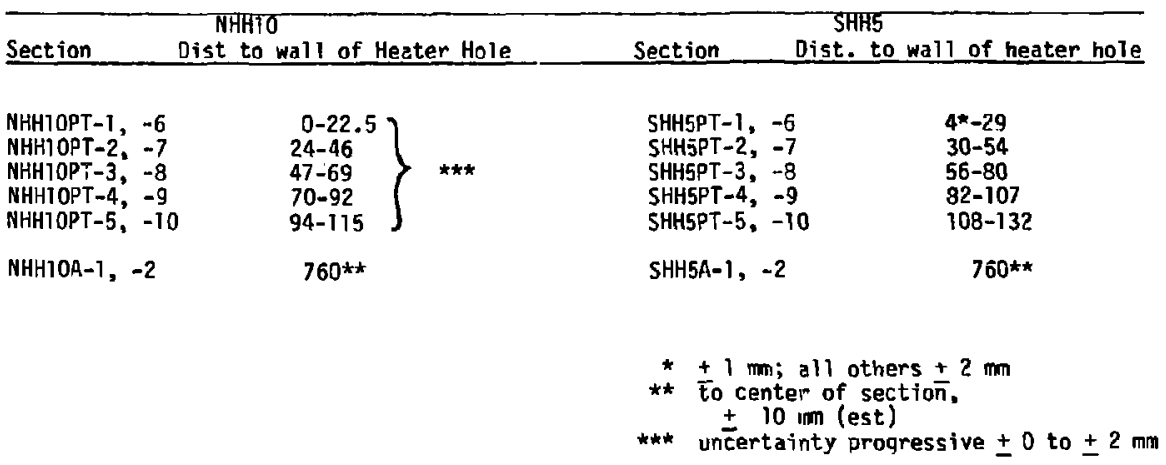


TABLE 2: Examination Sequence of SEM Sections

\section{First Scan}

\begin{tabular}{ccl} 
Sequence & & Section \\
\cline { 1 - 1 } 1 & & SHH5A-1 \\
2 & & SHH5PT-5 \\
3 & & SHH5PT-4 \\
4 & & SHH5PT-3 \\
5 & & SHH5PT-2 \\
6 & & SHH5PT-1 \\
7 & & NHH1OA-1 \\
8 & & NHH1OPT-5 \\
9 & & NHH1OPT-4 \\
10 & & NHH1OPT-3 \\
11 & & NHH1OPT-2 \\
12 & & NHH1OPT-1 \\
13 & & NHH10-1 \\
14 & & SHH5A-2 \\
15 & & SHH5PT-6 \\
16 & & SHH5PT-7 \\
17 & & SHH5PT-8 \\
18 & & SHH5PT-9 \\
19 & & SHH5PT-10 \\
20 & & SHH5-2 \\
21 & & NHH10-2 \\
22 & & NHH1OPT-6 \\
23 & & NHH1OPT-7 \\
24 & & NHH1OPT-8 \\
25 & & NHHIOPT-9 \\
26 & & NHH1OPT-10 \\
27 & & NHH1OA-2 \\
28 & & SHH5-1 \\
& &
\end{tabular}

Second Scan

\begin{tabular}{cll} 
Sequence & & Section \\
\hline 1 & & NHH1OA-1 \\
2 & & NHH1OPT-4 \\
3 & NHHIOPT-2 \\
4 & NHH1O-1 \\
5 & SHH5PT-1 \\
6 & SHH5PT-3 \\
7 & SHH5PT-5 \\
8 & SHH5A-2 \\
9 & SHH5PT-9 \\
10 & SHH5PT-7 \\
11 & SHH5-2 \\
12 & NHHIOPT-6 \\
13 & NHH1OPT-8 \\
14 & NHH1OPT-10 \\
15 & NHH10A-2 \\
16 & NHH1OPT-5 \\
17 & NHH1OPT-3 \\
18 & NHH1OPT-T \\
19 & SHH5-1 \\
20 & SHH5PT-2 \\
21 & SHH5PT-4 \\
22 & SHH5A-1 \\
23 & SHH5PT-10 \\
24 & SHH5PT-8 \\
25 & SHH5PT-6 \\
26 & NHH10-2 \\
27 & NHH1OPT-7 \\
28 & NHH1OPT-9
\end{tabular}


TABLE 3a: Number of Spots Photographed by Section*

Tctals, by

Heater Hole

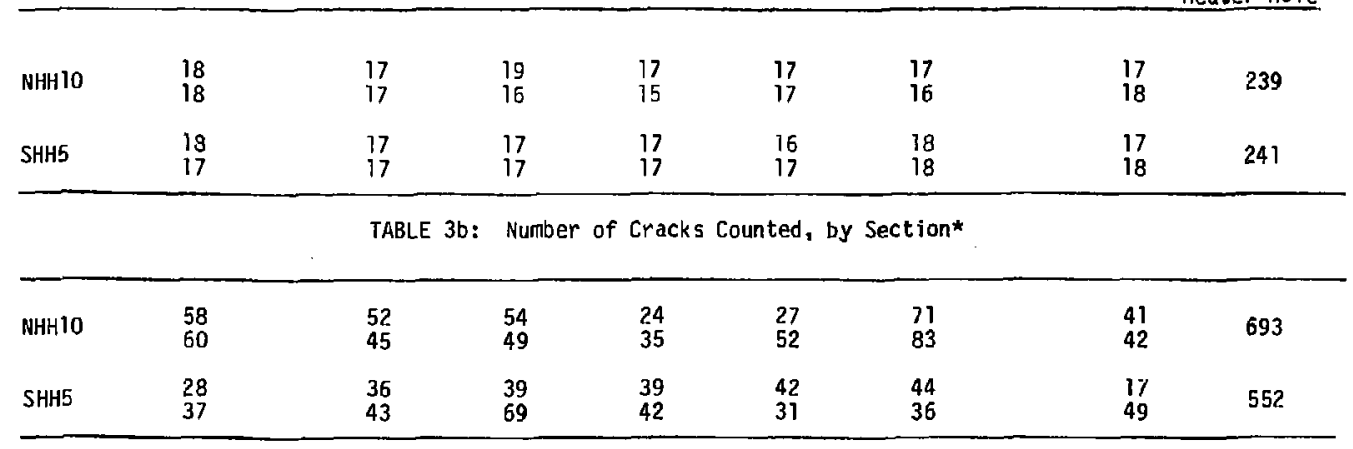

* Key to spatial arrangement of numbers in Tables 3-5 (arranged to resemble spatial arrangement of samples--see Figure i)

\begin{tabular}{llllllll}
\hline NHH10 & $\begin{array}{l}\text { NHH10-1 } \\
\text { NHH10-2 }\end{array}$ & $\begin{array}{l}\text { NHH1OPT-1 } \\
\text { NHH1OPT-6 }\end{array}$ & $\begin{array}{l}\text { NHH1OPT-2 } \\
\text { NHHIOPT-7 }\end{array}$ & $\begin{array}{l}\text { NHH1OPT-3 } \\
\text { NHHIOPT-B }\end{array}$ & $\begin{array}{l}\text { NHH1OPT-4 } \\
\text { NHH1OPT-9 }\end{array}$ & $\begin{array}{l}\text { NHH1OPT-5 } \\
\text { NHH1OPT-10 }\end{array}$ & $\begin{array}{l}\text { NHH1OA-1 } \\
\text { NHH1OA-2 }\end{array}$ \\
SHH5 & SHH5-1 & SHH5PT-1 & SHH5PT-2 & SHH5PT-3 & SHH5PT-4 & SHH5PT-5 & SHH5A-2 \\
& SHH5-2 & SHH5PT-6 & SHH5PT-7 & SHH5PT-8 & SHH5PT-9 & SHH5PT-10 & 5HH5A-1 \\
\hline
\end{tabular}


TABLE 4: Crack Counting Results*

(Mean \pm 1 std. dev., assuming informal distributions)

Density (number $/ \mathrm{mm}^{2}$ )

Totals by Heater Hole

\begin{tabular}{|c|c|c|c|c|c|c|c|c|}
\hline NHHIO & $\begin{array}{l}96+97 \\
99 \pm 83\end{array}$ & $\begin{array}{l}94+711 \\
91 \pm 95\end{array}$ & $\begin{array}{l}91+82 \\
93 \pm 85\end{array}$ & $\begin{array}{l}42+55 \\
69 \pm 67\end{array}$ & $\begin{array}{l}47+48 \\
93+81\end{array}$ & $\begin{array}{l}124+711 \\
154+85\end{array}$ & $\begin{array}{l}72+87 \\
69+64\end{array}$ & $87 \pm 86$ \\
\hline SHH5 & $\begin{array}{l}46 \pm 93 \\
65+81\end{array}$ & $\begin{array}{l}63+88 \\
75+68\end{array}$ & $\begin{array}{r}72+57 \\
120+99\end{array}$ & $\begin{array}{l}68+86 \\
73+90\end{array}$ & $\begin{array}{l}80+79 \\
54 \pm 52\end{array}$ & $\begin{array}{l}73+83 \\
59+58\end{array}$ & $\begin{array}{l}30+58 \\
91 \pm .98\end{array}$ & $69+80$ \\
\hline
\end{tabular}

Average length ( $1 \mathrm{~m})$

\begin{tabular}{lllllllll}
\hline NHH10 & $42+43$ & $45 \pm 44$ & $48+46$ & $61+62$ & $54+46$ & $42 \pm 51$ & $38+44$ & $40+42$ \\
& $30 \pm 35$ & $52 \pm 43$ & $36 \pm 41$ & $38 \pm 28$ & $47 \pm 40$ & $28 \pm 31$ & $28 \pm 31$ & \\
\multirow{4}{*}{ SHH5 } & $40 \pm 39$ & $24+31$ & $31+30$ & $45 \pm 54$ & $40+42$ & $26 \pm 31$ & $34+35$ \\
& $31 \pm 42$ & $36 \pm 42$ & $30 \pm 26$ & $39 \pm 36$ & $46 \pm 54$ & $43 \pm 38$ & $35+38$ \\
\hline
\end{tabular}

Length Density (mm/mm2)

\begin{tabular}{|c|c|c|c|c|c|c|c|}
\hline NHHTO & $\begin{array}{l}4.00+3.28 \\
2.97 \pm 3.00\end{array}$ & $\begin{array}{l}4.05+5.29 \\
3.94+4.50\end{array}$ & $\begin{array}{l}4.07+3.76 \\
3.24 \pm 3.93\end{array}$ & $\begin{array}{l}2.54+3.53 \\
2.66 \pm 2.66\end{array}$ & $\begin{array}{l}2.57+3.55 \\
3.79 \pm 3.80\end{array}$ & $\begin{array}{l}5.20+4.88 \\
4.32 \pm 1.97\end{array}$ & $\begin{array}{l}2.74+2.39 \\
7.97 \pm 2.22\end{array} 3.46+3.64$ \\
\hline SHH5 & $\begin{array}{l}1.85+2.57 \\
1.98+2.81\end{array}$ & $\begin{array}{l}1.54+2.39 \\
2.67+2.58\end{array}$ & $\begin{array}{l}2.19+2.10 \\
3.65+2.90\end{array}$ & $\begin{array}{l}3.03+3.35 \\
2.85+3.44\end{array}$ & $\begin{array}{l}3.11+3.67 \\
2.51+2.51\end{array}$ & $\begin{array}{l}1.90+2.15 \\
2.55+2.96\end{array}$ & $\begin{array}{l}0.66+1.20 \\
2.75+3.22\end{array} 2.38 \pm 2.79$ \\
\hline
\end{tabular}

*Table 3 gives key to arrangement of numbers 
TABLE 5. Average Length of Cracks*

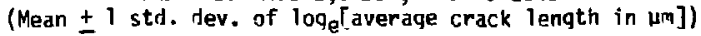

Totals by Heater Hole

\begin{tabular}{|c|c|c|c|c|c|c|c|c|}
\hline NHHIO & $\begin{array}{l}3.29+0.95 \\
2.88 \pm 1.05\end{array}$ & $\begin{array}{l}3.30+1.06 \\
3.47 \mp 1.05\end{array}$ & $\begin{array}{l}3.34+1.14 \\
2.99 \pm 1.16\end{array}$ & $\begin{array}{l}3.61 \pm 1.09 \\
3.41 \mp 0.70\end{array}$ & $\begin{array}{l}3.56+1.03 \\
3.30 \pm 1.04\end{array}$ & $\begin{array}{l}3.07+1.21 \\
2.89+0.96\end{array}$ & $\begin{array}{l}3.16+0.99 \\
2.83 \pm 1.02\end{array}$ & $3.17 \pm 1.06$ \\
\hline SHH5 & $\begin{array}{l}3.27+0.97 \\
2.87+1.00\end{array}$ & $\begin{array}{l}2.61+1.06 \\
3.04+1.06\end{array}$ & $\begin{array}{l}3.02+1.04 \\
3.05+0.91\end{array}$ & $\begin{array}{l}3.20+1.13 \\
3.28+0.91\end{array}$ & $\begin{array}{l}3.22+0.99 \\
3.28+1.06\end{array}$ & $\begin{array}{l}2.73+1.04 \\
3.36 \mp 0.99\end{array}$ & $\begin{array}{l}2.85+0.74 \\
3.02+1.06\end{array}$ & $3.05 \pm 1.02$ \\
\hline
\end{tabular}

*Table 3 qives key to arranqement of numbers 
TABLE 6. Crack Measurements Close to Heater Hole

(Measurements are given by spot, for four different sections)

\begin{tabular}{|c|c|c|c|c|c|c|c|c|c|c|c|}
\hline & --- & 4 & 6 & $---d f$ & $\underset{70}{\operatorname{ance}} \mathrm{fr}$ & $m_{12}^{w a l l}$ & of heate & $\begin{array}{l}\text { hole } \\
16\end{array}$ & (mm) 18 & 20 & 22 \\
\hline $\begin{array}{l}\text { Dens ity (number } / \mathrm{mm}^{2} \text { ) } \\
\text { NHHIOPT-1 } \\
\text { NHHIOPT-6 }\end{array}$ & $\begin{array}{l}59 \\
59\end{array}$ & $\begin{array}{r}0 \\
30\end{array}$ & 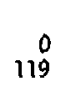 & $\begin{array}{l}30 \\
59\end{array}$ & 237 & $\begin{array}{r}0 \\
148\end{array}$ & $\begin{array}{l}30 \\
89\end{array}$ & $\begin{array}{l}30 \\
59\end{array}$ & & 0 & 0 \\
\hline $\begin{array}{l}\text { SHH5PT-1 } \\
\text { SHH5PT-6 }\end{array}$ & & & 0 & $\begin{array}{r}326 \\
89\end{array}$ & $\begin{array}{r}0 \\
89\end{array}$ & $\begin{array}{r}59 \\
0\end{array}$ & 30 & $\begin{array}{r}59 \\
178\end{array}$ & $\begin{array}{l}59 \\
30\end{array}$ & $\begin{array}{l}30 \\
59\end{array}$ & $\begin{array}{r}0 \\
178\end{array}$ \\
\hline $\begin{array}{l}\text { Average length }(\mathrm{um}) \\
\text { NHHIOPT-1 } \\
\text { NHH IOPT-6 }\end{array}$ & $\begin{array}{l}47 \\
36\end{array}$ & $\begin{array}{r}0 \\
189\end{array}$ & $\begin{array}{r}0 \\
66\end{array}$ & $\begin{array}{l}27 \\
96\end{array}$ & $\begin{array}{r}0 \\
50\end{array}$ & $\begin{array}{l}47 \\
14\end{array}$ & $\begin{array}{l}48 \\
42\end{array}$ & $\begin{array}{r}0 \\
20\end{array}$ & 0 & & \\
\hline $\begin{array}{l}\text { SHH5PT-1 } \\
\text { SHH5PT-6 }\end{array}$ & & & 0 & $\begin{array}{r}7 \\
14\end{array}$ & $\begin{array}{r}0 \\
49\end{array}$ & $\begin{array}{r}12 \\
0\end{array}$ & 37 & $\begin{array}{r}9 \\
14\end{array}$ & $\begin{array}{l}35 \\
28\end{array}$ & $\begin{array}{r}8 \\
113\end{array}$ & $\begin{array}{r}0 \\
34\end{array}$ \\
\hline $\begin{array}{l}\text { Length density }\left(\mathrm{mm} / \mathrm{mm}^{2}\right) \\
\text { NHHIOPT-1 } \\
\text { NHH1OPT-6 }\end{array}$ & $\begin{array}{l}2.79 \\
2.16\end{array}$ & $\begin{array}{c}0 \\
5.62\end{array}$ & ${ }^{0} .82$ & $\begin{array}{l}0.81 \\
5.70\end{array}$ & $\stackrel{0}{11.83}$ & $\begin{array}{l}1.40 \\
2.11\end{array}$ & $\begin{array}{l}1.43 \\
3.71\end{array}$ & $\begin{array}{l}0 \\
1.20\end{array}$ & 0 & & \\
\hline $\begin{array}{l}\text { SHH5PT-1 } \\
\text { SHH5PT-6 }\end{array}$ & & & 0 & $\begin{array}{l}2.31 \\
1.29\end{array}$ & $\begin{array}{l}0 \\
4.33\end{array}$ & 0.74 & 1.10 & $\begin{array}{l}0.55 \\
2.57\end{array}$ & $\begin{array}{l}2.07 \\
0.84\end{array}$ & $\begin{array}{l}0.24 \\
6.73\end{array}$ & $\begin{array}{l}0 \\
6.07\end{array}$ \\
\hline
\end{tabular}


TABLE 7. Modal Analyses (vol\% of NHHIOPT Samples)

\begin{tabular}{|c|c|c|c|c|c|c|}
\hline \multirow{2}{*}{\multicolumn{2}{|c|}{$\begin{array}{l}\text { Average } \\
\text { Deuterjc } \\
\end{array}$}} & \multicolumn{5}{|c|}{ NHH1OPT } \\
\hline & & 1 & 2 & 3 & 4 & 5 \\
\hline Plaqioclase & $42.85 \pm 1.08$ & 46.1 & 36.5 & 43.8 & 37.4 & 56.4 \\
\hline K-Feldspar & $17.97 \pm 0.82$ & 17.3 & 21.9 & 23.7 & 25.2 & 18.2 \\
\hline Quartz & $27.17 \pm 1.23$ & 25.7 & 25.6 & 19.9 & 26.2 & 17.0 \\
\hline Biotite & $5.38 \pm 0.53$ & 5.6 & 8.9 & 6.3 & 3.0 & 3.6 \\
\hline Muscovite & $1.48 \pm 0.28$ & 1.8 & 2.9 & 1.7 & 2.5 & 0.6 \\
\hline Chlorite & $0.99 \pm 0.18$ & 1.3 & 1.6 & 2.0 & 1.9 & 1.4 \\
\hline Calsite & $0.30 \pm 0.08$ & 0.0 & 0.0 & 0.0 & 0.5 & 0.6 \\
\hline Czo/Ep & $0.73 \pm 0.07$ & 0.4 & 0.6 & 0.8 & 1.6 & 1.0 \\
\hline Titanite & $0.44 \pm 0.10$ & 0.6 & 0.4 & 0.5 & 0.3 & 0.4 \\
\hline Magnet ite & $0.78 \pm 0.10$ & 1.1 & 1.1 & 1.0 & 1.0 & 0.5 \\
\hline Rutile & 0.00 & 0.0 & 0.0 & 0.0 & 0.0 & 0.0 \\
\hline Pyrite & $0.03 \pm 0.03$ & 0.0 & 0.0 & 0.0 & 0.3 & 0.1 \\
\hline Accessories 2 & 0.33 & 0.0 & 0.5 & 0.3 & 0.7 & 0.2 \\
\hline
\end{tabular}


TABLE 8. Analyses of Feldspars from MHHIOPT

\begin{tabular}{|c|c|c|c|c|c|c|}
\hline \multirow[b]{2}{*}{ Sample } & \multicolumn{3}{|c|}{ K-Feldspar } & \multicolumn{3}{|c|}{ Plagioclase } \\
\hline & No. of Analyses & Avg. & 5.0 & Ne. of Analyses & Avg: & S.D. \\
\hline NHHIOPT-1 & 47 & 89.8 & 4.3 & 101 & 29.8 & 9.5 \\
\hline NHHIOPT-2 & 60 & 89.7 & 5.5 & 97 & 31.3 & 13.8 \\
\hline NHHTOPT-3 & 74 & 87.4 & 11.4 & 149 & 30.7 & 9.2 \\
\hline NHH10PT-4 & 67 & 89.9 & 5.9 & 87 & 30.6 & 9.2 \\
\hline NHHTOPT-5 & 15 & 91.0 & $7 / 2$ & 50 & 34.0 & 9.5 \\
\hline Average & & 89.7 & & & 31.3 & \\
\hline
\end{tabular}




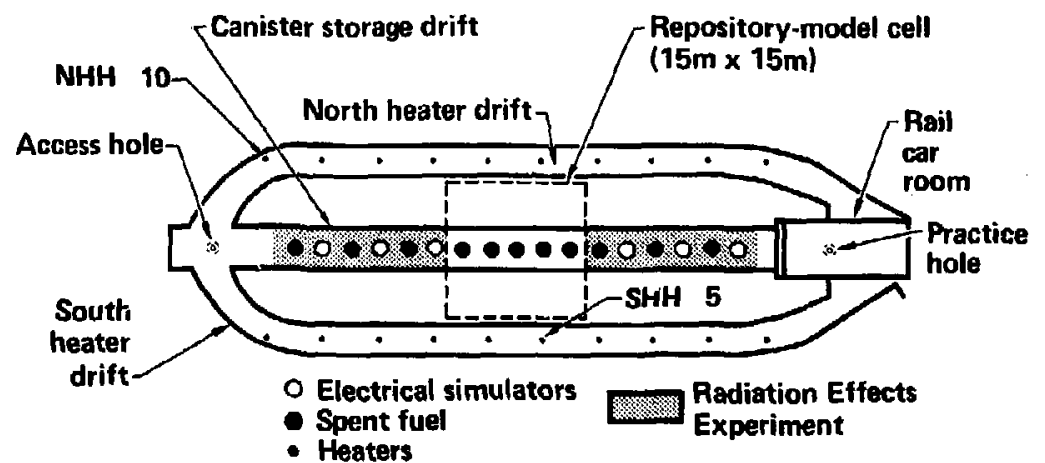

Fig. 1. Plan view of the layout of the SFT-C showing the principal features of the overall experiment. Material examined in this study was taken from the vicinity of heater drift boreholes NHHTO and SHH5. 


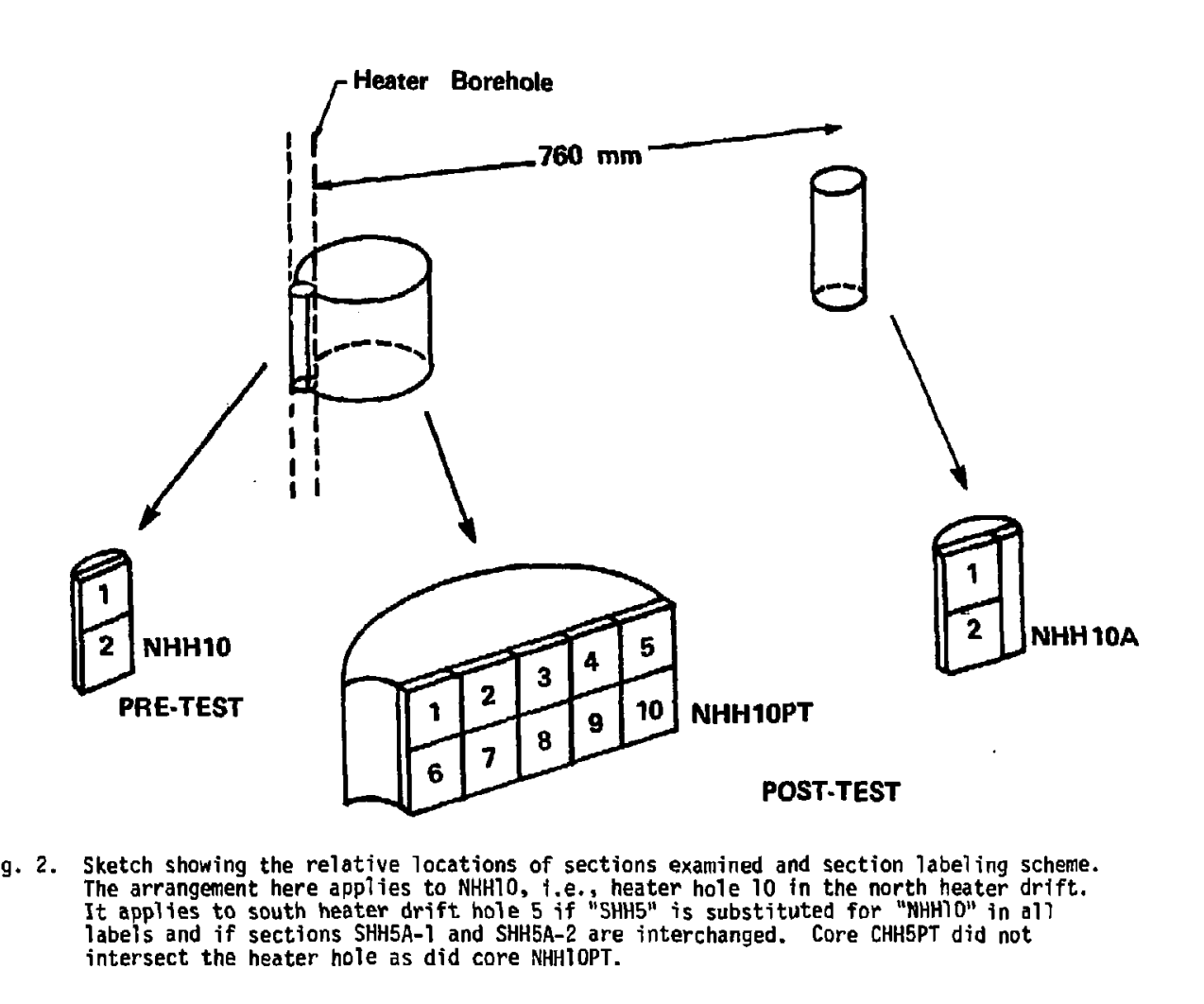



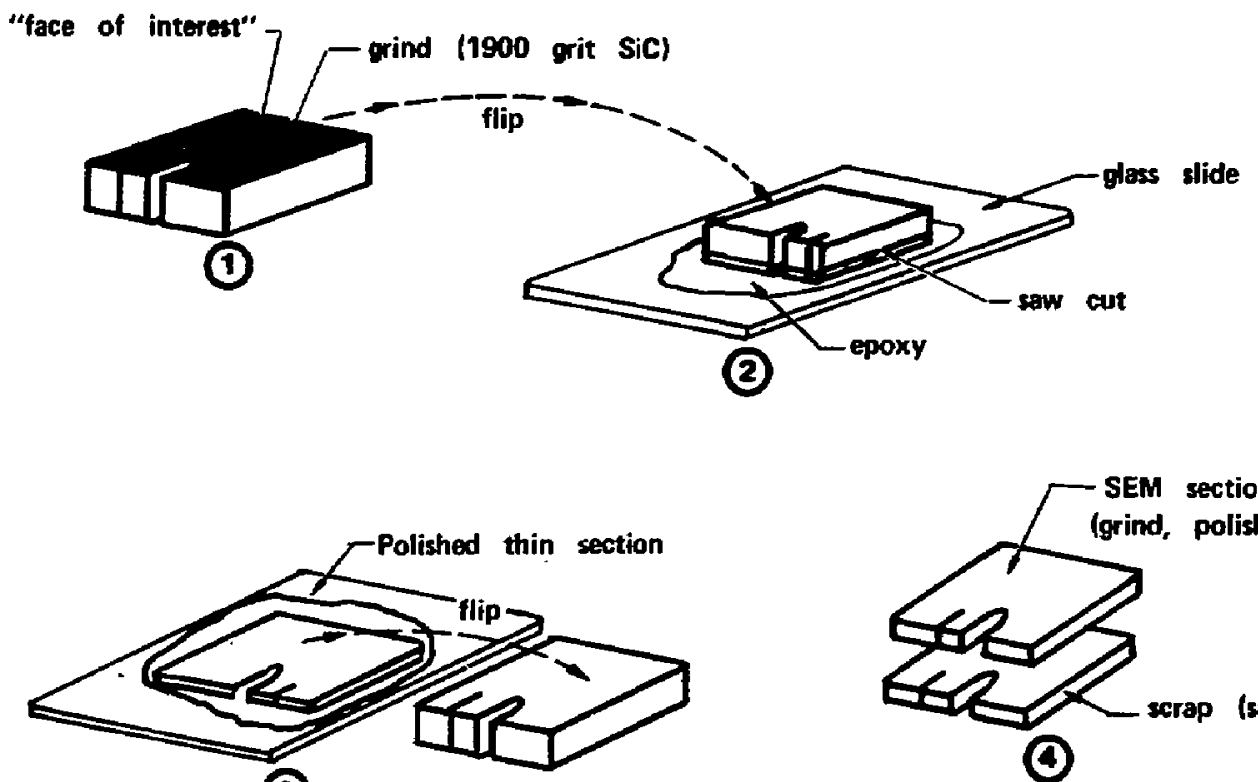

(3)

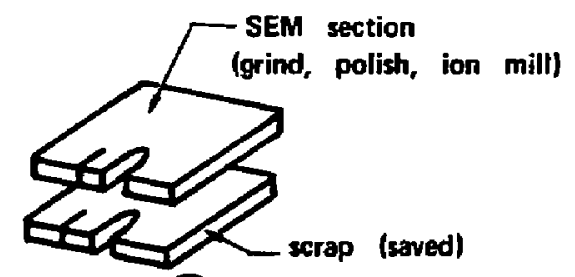

()

Fig. 3. Steps in sample preparation of sections for SEM and OM analysis. 


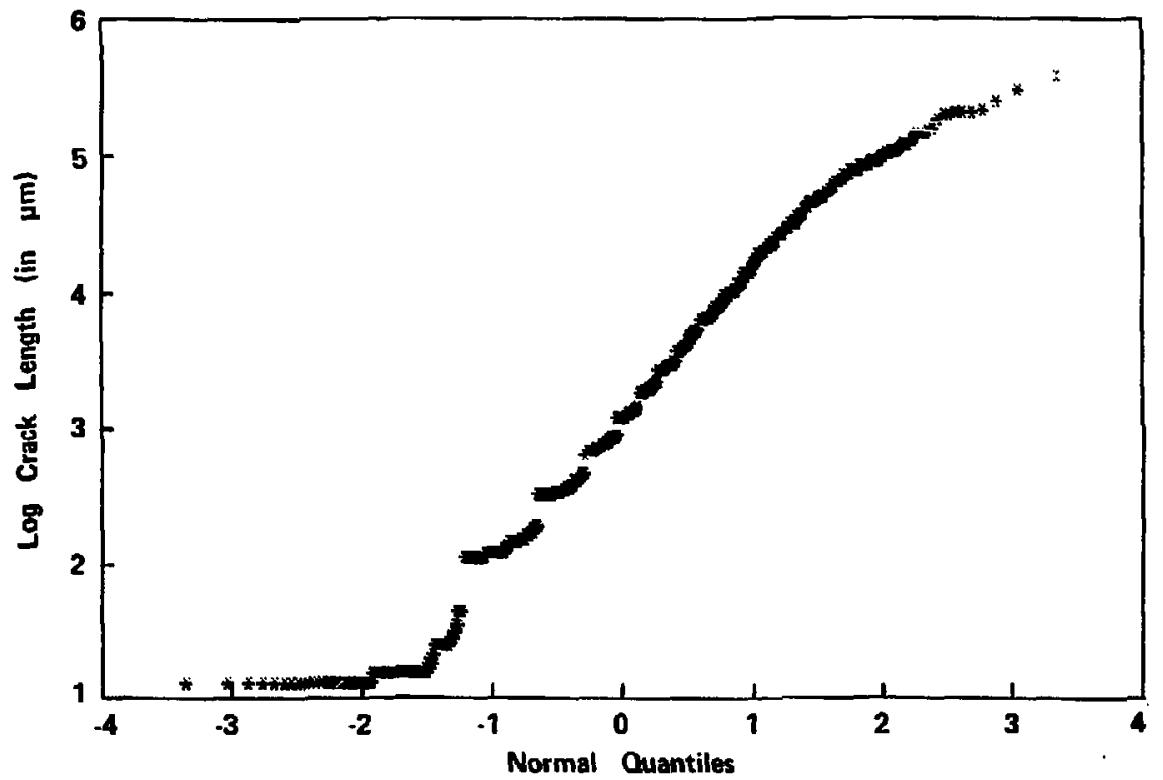

Fig. 4. Quantile-quantile (QQ) plot of $10 \mathrm{~g}$ length of al1 1245 cracks counted, demonstrating by its linearity the log-normal distribution of those lengths. The bottom end of the $Q Q$ plot is pushed up by a round-off error in digitization which forces all percefved cracks to have a minimum length of about $3 \mathrm{~m}$. The top end is suppressed by truncation of long cracks at the edges of the photograph. 


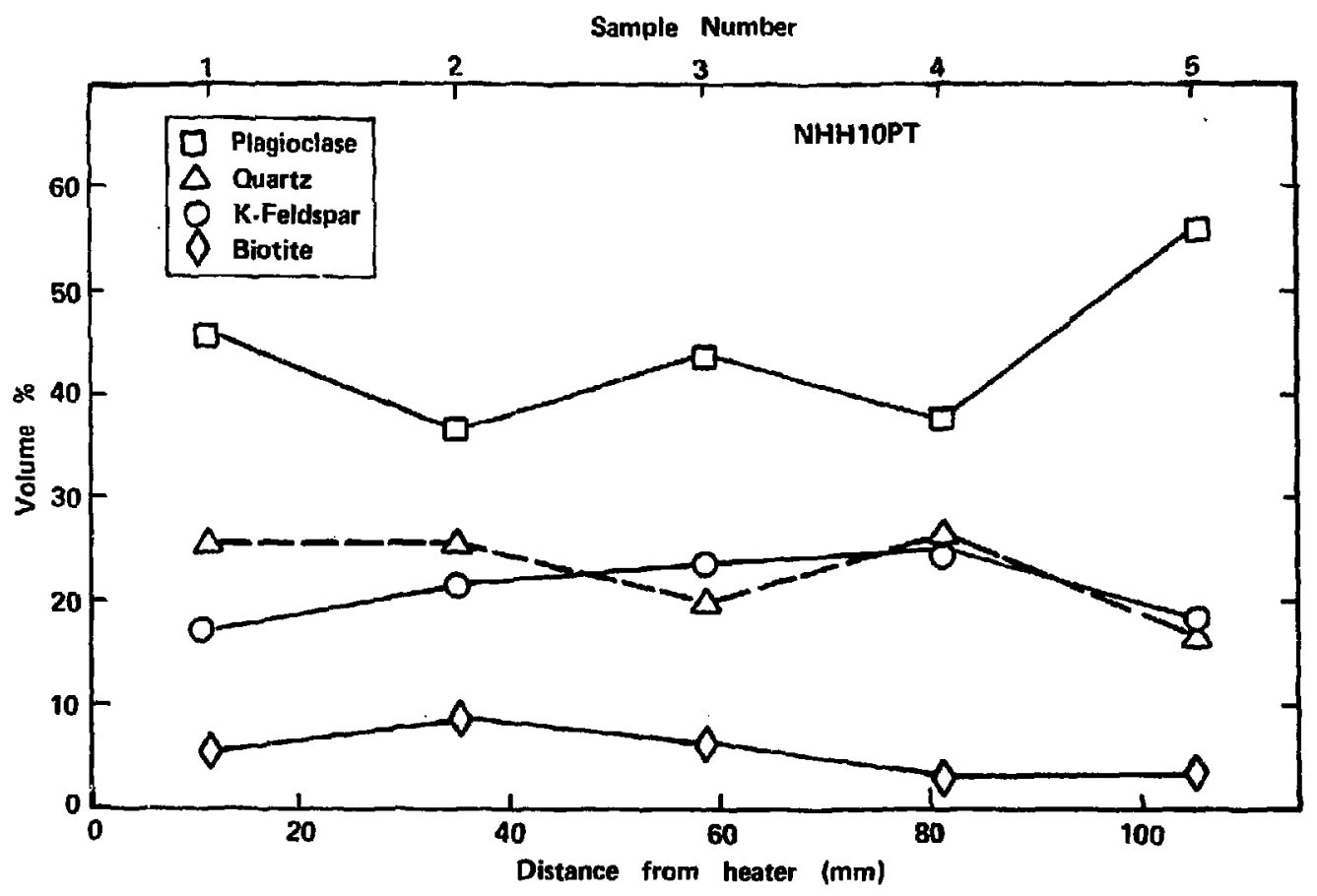

Fig. 5. Modal abundances of plagioclase, K-feldspar, quartz and biotite in. NHHIOPT samples relative to the heater. 


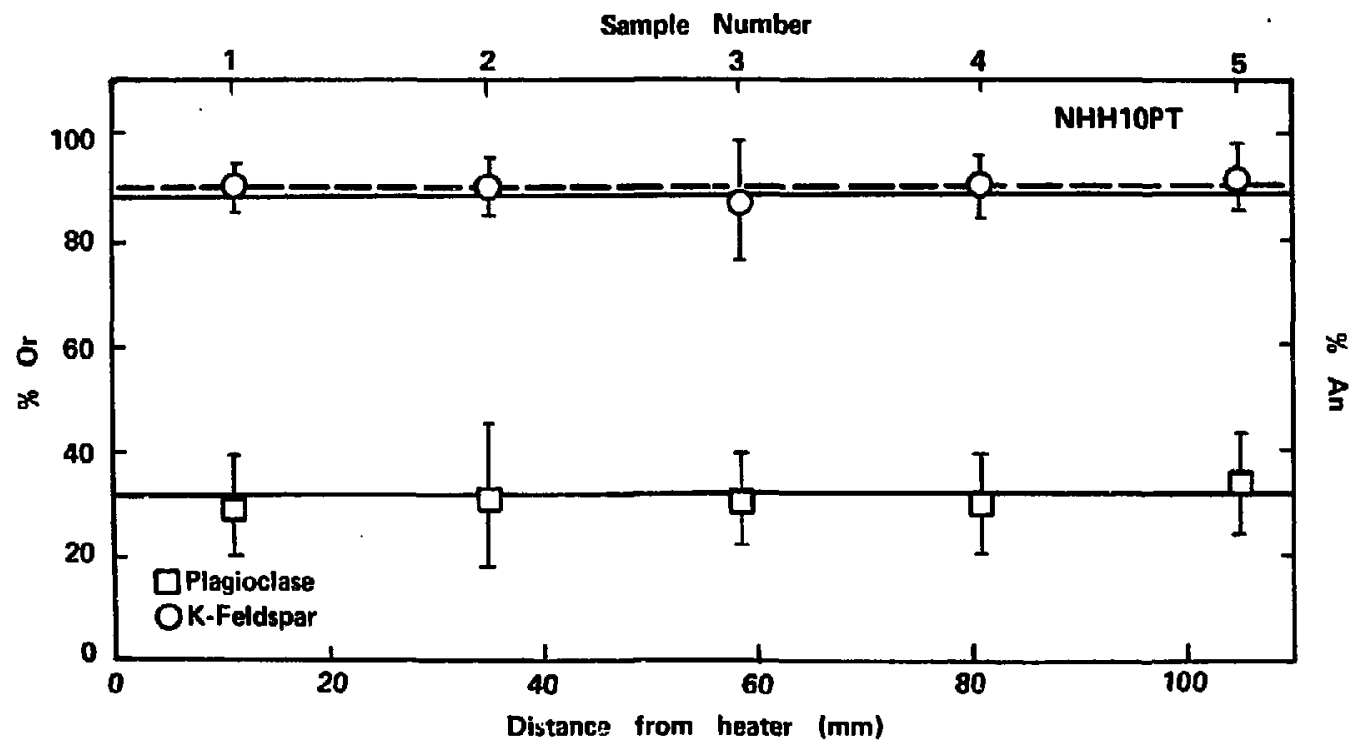

F19. 6. Yariation in feldspar compositions in NHHIOPT samples relative to the heater. Dashed lines are the average compositions from NHHIOPT samples, and solid 7 ines are the average of all pre-test samples (Patrick et al., 1984). 